\title{
PRELIMINARY STUDY ON THE PALM FLORA OF THE LORE LINDU NATIONAL PARK, CENTRAL SULAWESI, INDONESIA
}

\author{
JOHANIS P. MOGEA
}

Herbarium Bogoriense, Research Center for Biology, LIPI, Bogor. Indonesia

\begin{abstract}
The population size, structure, and composition of the palm flora in a $1350 \mathrm{~m}$ by $20 \mathrm{~m}$ rectangular plot in Gunung Potong and a $1500 \mathrm{~m}$ by $20 \mathrm{~m}$ rectangular plot in Tongoa were measured. The total palm species from both plots numbered 33 represented by 8 genera. Eight species, namely Calamus omatus var. celebicus, Pinanga caesia, Arenga pinnata, Daemonorops sp.3. Calamus didymocarpus. Calamus sp.4 (rapid spines), Caryota mitis, andAreca vestiaria have relatively high frequency values ranging from $5.46 \%$ to $10.66 \%$. In addition, palm specimens previously collected from the park were examined at Herbarium Bogoriense to set up a preliminary checklist. So far, the national park is recorded as having 48 palm species represented by 11 genera which give figures of about $68 \%$ species and $58 \%$ genera of the total native Sulawesi palm flora. Though the number of endemic palms in Sulawesi is high (72\%), namely 51 out of total native 71 species, only two species are locally endemic to Central Sulawesi namely Gronophyllum sarasinorum and Pinanga sp. nov. 1 (longirachilla). So far only the latter species is endemic to the national park.
\end{abstract}

Key words: palm diversity/Lore Lindu National Park/Sulawesi/Indonesia/endemic species

\section{INTRODUCTION}

With emphasis on the sustainable use of biological diversity and its conservation, the Indonesian-German Research Program had initiated a comprehensive interdisciplinary research funded by the German Research Council (DFG) for a duration of 15 years beginning in 2000. The Program will be evaluated every three years. The research partners are two universities from Germany namely, Gottingen and Kassel, and two from Indonesia, Bogor Agricultural University (IPB, Bogor) and University of Tadulako (UNTAD, Palu). The overall goal is to identify factors which cause changes in forest margin areas. Therefore, the Program is known as "Stability of Rainforest Margins" abbreviated as STORMA. In addition to the research program, a development of related sciences, manpower and laboratory equipment are also provided. The field of research consists of social and economic dynamics, water and nutrient turnover, biological diversity, and land use systems. The location used for the research is in and around the Lore Lindu National Park, Central Sulawesi, Indonesia (Fig. 1).

Within this framework, an exploration of knowledge on palm diversity in and around the Lore Lindu National Park is being conducted. The present paper reports a preliminary study, based mainly on the field observations made during the two weeklong field trips to the national park in November 2000 and March 2001, as well as examination of earlier herbarium collections at Herbarium Bogoriense. 


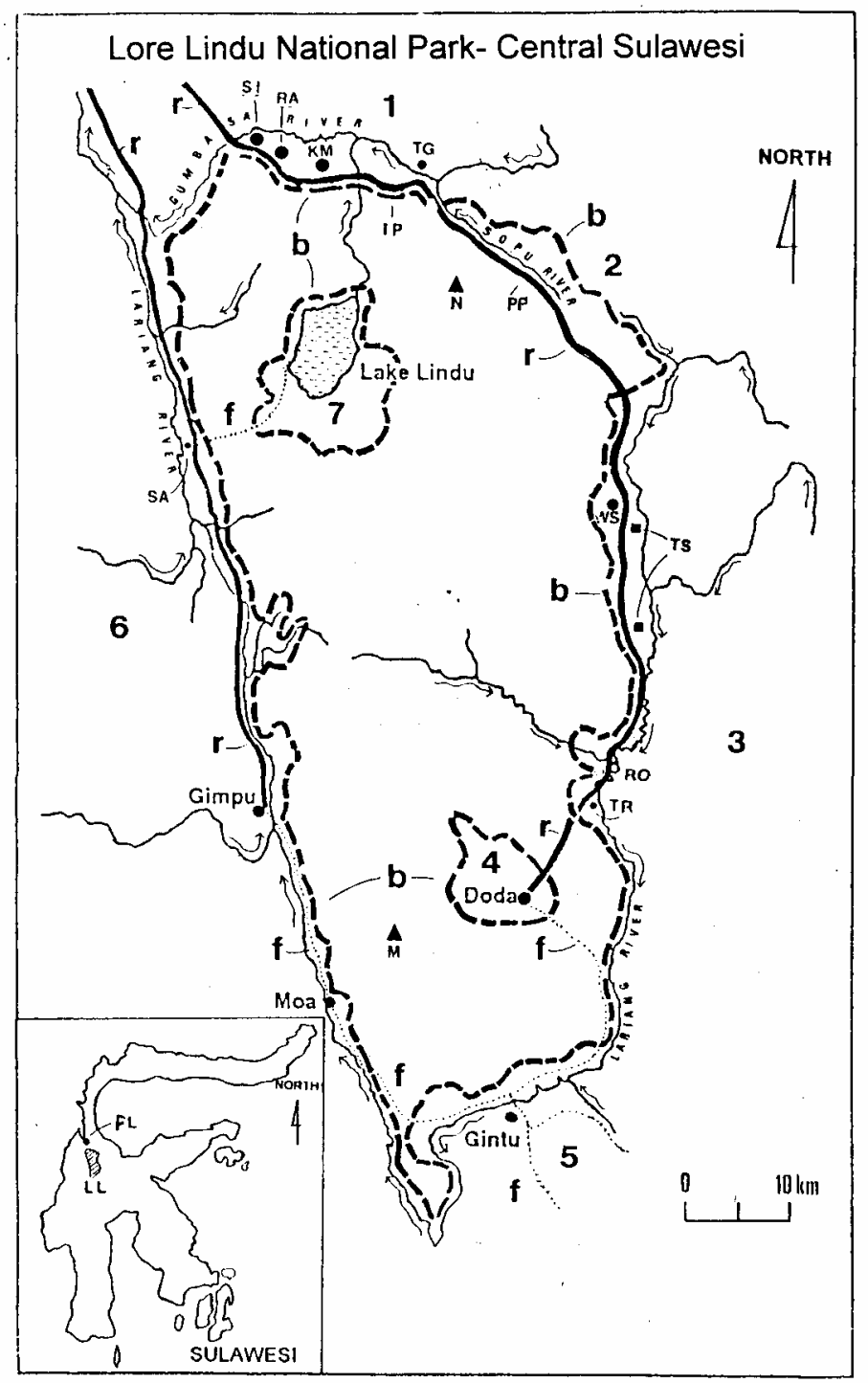

Figure 1. Valley study sites map in and around the Lore Lindu National Park, Central Sulawesi

1. Palolo, 2. Sopu, 3. Napu, 4. Besoa, 5. Bada, 6. Kulawi, and 7. Lindu. Mountains and others: N: Gunung Nokilalaki, M: Gunung Malemo, b: boundary of the national park,f: foot path, r: road. Location: KM: Kamarora, LL: Lore Lindu National Park, PL: Palu, PP: Gunung Potong plot, RA : Rahmat, RO : Rompo, SA : Sadaunta, SI : Sintuwu, TO : Tongoa,TP : Tongoa plot, TR: Torire, TS: Transmigration sites, WS: Wuasa. 
The Lore Lindu National Park covers 217000 ha of lowland and montane rainforest. Approximately $70 \%$ of the Park lies between elevations of 1000 to $1500 \mathrm{~m}$, and less than $10 \%$ is below $1000 \mathrm{~m}$. The highest place located south of Tongoa is the summit of Gunung (Mount) Nokilalaki at elevation 2355 m, the other summit is located south of the Park namely Gunung Malemo at 2263 m (Mogea \& Suhardjono 1981). Three big rivers drain the Park, namely Lariang, Gumbasa, and Sopu. The headwaters of Lariang drain at the eastern part of the Park, then flow to the south and round to the west then to the north of the Park. Near Gimpu, the river divides into two branches, one to the west ending in the west coast in South Sulawesi, the other branch to the north of the Park joins the Gumbasa river and ends at the coast near Palu. The upper Gumbasa river is the outlet of Lake Lindu. It flows to the north around Kamarora and Sintuwu then unified with Lariang. The lake is located at west of Gunung Nokilalaki. At the eastern north of the Park flows Sopu river, its lower reaches join at the Gumbasa river. Two enclaves in the Park are excluded from the national park, namely Lindu and Besoa valleys. Five other valleys are located around the Park, namely Palolo, Sopu, Napu, Bada, and Kulawi. There are two moderate roads available for large and public vehicles. The west is a route from Palu to Gimpu through Kulawi valley outside the Park. The east road is a route from Palu to Doda. The road segments near Tongoa to Wuasa, and Torire to Doda are through the eastern part of the Park. The road from Wuasa to Rompo in November 2000 was badly damaged, therefore it can only be transversed by a four-wheel drive vehicle

(Fig. 1).

Further basic information of the Park is presented in the Indonesian Program Information Sheet of the Nature Conservancy (TNC 2000).

\section{MATERIALS AND METHODS}

The sites selected for the study were at Tongoa, Gunung Potong, Rompo, Moa, Gimpu, and Sadaunta (Fig. 1). A national park topographical map, 12XL Garmin GPS, and altimeter were used to locate the site and to measure the elevation. Paln $\backslash$ diversity was analyzed in each site using a modified Mueller-Dombois \& Ellenberg (1974) rectangular plot transect. The transects were established from the lowest elevation on each site to the highest evaluation preferably following an existing foot path. For these two trips, palm diversity was studied in two sites. The first site was in a new cruising transect of Gunung Potong from $850 \mathrm{~m}$ to $1250 \mathrm{~m}$ altitude, on the plot of 1350 × 20 m; and the second site was in Tongoa on a foot path to the summit of Gunung Nokilalaki, at an average altitude of $750 \mathrm{~m}$, on the plot of $1500 \times 20 \mathrm{~m}$. Each plot consisted of many rectangular subplots of $50 \times 20 \mathrm{~m}$ for observation of either solitary or clustered young and mature palms. For the sapling's study, each subplot consisted of one sapling square plot of $5 \times 5 \mathrm{~m}$ and one seedling square plot of $1 \times 1 \mathrm{~m}$ for observation of seedling coverage. Through this study, species density, frequency, cover dominance, important value, structure, composition, and palm 
population dynamics can be calculated. During the field observation, voucher specimens were made. Herbarium specimens, ripe fruits, and living seedlings were collected when necessary, particularly for proper identification and ex. situ conservation. Herbarium duplicates are deposited in Herbarium Celebense (CEB) at the University of Tadulako in Palu, Herbarium Bogoriense (BO), Netherlands National Herbarium Leiden Branch (L), and Herbarium of the Royal Botanic Gardens Kew (K). Palm collecting followed standard methods; for rattans a method introduced by Dransfield (1974) was followed. Palm classification is in accordance with the Genera Palmarum which was introduced by Uhl \& Dransfield (1987). Temporary herbarium specimen preservation followed a modified Schweinfurth Technique (Steenis 1950). Identification was done in the field as well as at BO and CEB. To facilitate remembering unfamiliar or unidentified taxon in the field, a temporary nickname based on its significant morphological character was applied, hence in this paper a name like Calamus sp.8 (tuberosus) or Calamus sp.2 (ligule) is used. In addition, sketch drawings and digital photographs were made. Field observations were supported by examination of 61 herbarium specimens at BO. New taxa will be described and published in separate papers.

\section{RESULTS AND DISCUSSIONS}

During identification of palms from the study sites, it was found that 15 taxa of Calamus and 4 taxa of Daemonorops (Table 2) need further identification particularly due to either incomplete herbarium specimens or lack of specimen types at BO, or a need for taxonomic revision. Hence, naming these palms required three ways. The first is the taxon's name based on its morphological similarity to a related species, hence the epithet "aff." is used, such as Calamus aff. C. zollingeri. The second is an expression of its significant character, such as when the taxon typically has long ligule, then the taxon is called Calamus sp.2 (ligule). Another example is where there is no spine on its knee (Fig. 7-9), the taxon is called Calamus sp. 1 (knee no spine). The third is when the epithet required long sentence to define the taxon, then it is called for example Daemonorops sp.3 (Table 2).

Some taxa are definitely new species, but their description is not published yet, hence the name is informal, such as Calamus sp. nov.l (ahlidurii). The latter case is found as well as in Caryota, Gronophyllum, Gulubia, and Pinanga (Tables 2 and 3).

The number of species from both the Gunung Potong and Tongoa plots is 33 which belong to 8 genera (Table 1). Calamus is represented by 20 species, among them are the well-known commercial rattans namely 'batang' (C. zollingeri), 'lambang' (C. ornatus var. celebicus), 'tohiti' (C. inops), and 'ombol' (C. symphysipus)', Daemonorops represented by five species, among them is an edible young sweetest cabbage 'uwe manis' (D. macropterus); Pigafetta represented by P. elata, an ornamental tree palm known as 'wanga' (Fig. 6). This palm, for about three decades, was misidentified as P.filaris (Dransfield 1998). 
Preliminary study on the palm flora of the Lore Lindu National Park - Johanis P. Mogea

Table 1. Absolute (FA) and relative frequency (FR) of palms from 27 subplots in Gunung Potong (P) and 30 subplots in Tongoa (T). Subplot size is rectangular $50 \mathrm{~m}$ by $20 \mathrm{~m}$

\begin{tabular}{|c|c|c|c|c|}
\hline & $P$ & $\mathrm{~T}$ & FA & FR $(\%)$ \\
\hline Calamus ornatus var. celebicus & 17 & 24 & 41 & 10.66 \\
\hline Pinanga caesia & 27 & 13 & 40 & 10.40 \\
\hline Arenga pinnata & 08 & 25 & 33 & 08.58 \\
\hline Daemonorops sp. 3 & 10 & 22 & 32 & 08.32 \\
\hline Calamus sp.l (knee no spine) & 14 & 15 & 29 & 07.54 \\
\hline Calamus sp.4 (rapid spines) & 10 & 19 & 29 & 07.54 \\
\hline Caryota mitis & 07 & 21 & 28 & 07.28 \\
\hline Areca vestiaria & 01 & 20 & 21 & 05.46 \\
\hline Calamus sp.2 (ligule) & 10 & 01 & 11 & 02.86 \\
\hline Calamus zollingeri & 06 & 05 & 11 & 02.86 \\
\hline Calamus sp.8 (tuberosus) & 06 & 02 & 08 & 02.08 \\
\hline Caryota rumphiana & 05 & 01 & 06 & 01.56 \\
\hline Daemonorops sp.I & 04 & 02 & 06 & 01.56 \\
\hline Calamus aff. C. paspalanthus & 09 & -- & 09 & 02.34 \\
\hline Calamus ahlidurii & 04 & -- & 04 & 01.04 \\
\hline Calamus sp. 3 (longispinus) & 03 & -- & 03 & 00.78 \\
\hline Calamus sp. 5 (regular) & 03 & -- & 03 & 00.78 \\
\hline Calamus sp.6 (soft white spine) & 03 & -- & 03 & 00.78 \\
\hline Calamus sp.7 (tattered ligule) & 03 & + & 03 & 00.78 \\
\hline Calamus inops & 03 & -- & 03 & 00.78 \\
\hline Calamus aff. $\mathrm{C}$. ciliaris & 02 & - & 02 & 00.52 \\
\hline Daemonorops macropterus & 02 & - & 02 & 00.52 \\
\hline Pigafetta elata & 02 & -- & 02 & 00.52 \\
\hline Calamus aff. C. reinwardtii & -. & 18 & 18 & 04.68 \\
\hline Arenga undulatifolia & - & 14 & 14 & 03.64 \\
\hline Daem. sp. 1 (didymophylla) & -- & 12 & 12 & 03.12 \\
\hline Korthalsia celebica & - & 10 & 10 & 02.60 \\
\hline Calarnus symphysipus & -- & 03 & 03 & 00.78 \\
\hline Calamus aff. C. zollingeri & - & 02 & 02 & 00.52 \\
\hline Calamus aff. C. inops & - & 01 & 01 & 00.26 \\
\hline Calamus aff. C. javensis & -- & 01 & 01 & 00.26 \\
\hline Calamus aff. C. ornatus & -- & 01 & 01 & 00.26 \\
\hline Daemonorops sp.4 & -- & 01 & 01 & 00.26 \\
\hline Total number of subplot frequency & & & 392 & 101.92 \\
\hline
\end{tabular}


BIOTROPIA NO. 18, 2002

Table 2. Checklist of palms in the Lore Lindu National Park

\begin{tabular}{|c|c|c|c|c|c|}
\hline NO. & SPECIES NAME & $\begin{array}{c}\text { NO. } \\
\text { GENUS }\end{array}$ & NO. & SPECIES NAME & $\begin{array}{c}\text { NO. } \\
\text { GENUS }\end{array}$ \\
\hline 01. & Areca catechu & 1 & 25. & Calamus sp. 3 (longispinus) & \\
\hline 02. & Areca vestiaria & & 26. & Calamus sp.4 (rapid spines) & \\
\hline 03. & Arenga pinnata & 2 & 27. & Calamus sp.5 (regular) & \\
\hline 04. & Arenga undulatifolia & & 28 & Calamus sp.6 (soft white spine) & \\
\hline 05. & Calamus didymocarpus & 3 & 29. & Calamus sp.7 (tattered ligule) & \\
\hline 06. & Calamus leicaulis & & 30. & Calamus sp.8 (tuberosus) & \\
\hline 07. & Calamus leptostachys & & 31. & Caryota mitis & 4 \\
\hline 08. & Calamus macrosphaerion & & 32. & Caryota rumphiana & \\
\hline 09. & Calamus minahassae & & 33. & Caryota sp. nov.l (angustifolia) & \\
\hline 10 & Calamus inops & & 34. & Cocos nucifera & 5 \\
\hline 11. & Calamus ornatus var. celebicus & & 35. & Daemonorops macropterus & 6 \\
\hline 12. & Calamus othrostachyus & & 36. & Daemonorops robusta & \\
\hline 13. & Calamus symphysipus & & 37. & Daemonorops sp.1 (didymophylla) & \\
\hline 14. & Calamus zollingeri & & 38. & Daemonorops sp.2 & \\
\hline 15. & Calamus sp. nov.1 (ahli durii) & & 39. & Daemonorops sp. 3 & \\
\hline 16. & Calamus aff. C. ciliaris & & 40. & Daemonorops sp.4 & \\
\hline & Calamus aff. C. inops & & 41. & Korthalsia celebica & 7 \\
\hline & Calamus aff. C. javensis & & 42. & Licuala celebica & 8 \\
\hline & Calamus aff. C. ornatus & & 43. & Livistona rotundifolia & 9 \\
\hline & Calamus aff. C. paspalanthus & & 44. & Pigafetta elata & 10 \\
\hline & Calamus aff. C. reinwardtii & & 45. & Pinanga caesia & 11 \\
\hline & Calamus aff. C. zollingeri & & 46 & Pinanga sp. nov.l (longirachilla) & \\
\hline & Calamus sp.I (knee no spine) & & 47. & Pinanga sp. nov. 2 (rubiginosa) & \\
\hline 24. & Calamus sp.2 (ligule) & & 48. & Pinanga sp. nov. 3 (tenuirachis) & \\
\hline
\end{tabular}

Table 3. Checklist of native Sulawesi palms, local name, and geographical distribution 2000

\begin{tabular}{|c|c|c|c|c|c|}
\hline No. & BOTANICAL NAME & NG & $\begin{array}{l}\text { LOCAL } \\
\text { NAME }\end{array}$ & GEOGRAPHICAL & $\begin{array}{l}\text { DISTRI- } \\
\text { BUTION }\end{array}$ \\
\hline 01. & Cocos nucifera $L$. & 01 & kelapa & Tropical Asia & Group 1 \\
\hline 02. & Livistona rotundifolia (Lam.) Mart. & 02 & woka & Tropical Asia & \\
\hline 03. & Nypa fruticans Wurmb. & 03 & nipah & Tropical Asia & \\
\hline 04. & Oncosperma horridum Scheff. & 04 & nibung & Tropical Asia & \\
\hline 05. & Pholidocarpus maiadum Becc. & 05 & matayangan & Tropical Asia & \\
\hline 06. & Borassus flabellifer $\mathrm{L}$. & 06 & lontar & Tropical Asia & \\
\hline 07. & Areca catechu $L$. & 07 & pinang sirih & Malesia & Group 2 \\
\hline 08. & Arenga pinnata (Wurmb) Merr. & 08 & aren, saguer & Malesia & \\
\hline 09. & Caryota mitis Lour. & 09 & --- & Malesia & \\
\hline 10. & Corypha utan Lam. & 10 & gebang & Malesia & \\
\hline 11. & Licuala spinosa Wurmb & 11 & -- & Malesia & \\
\hline
\end{tabular}


Preliminary study on the palm flora of the Lore Lindu National Park - Johanis P. Mogea

Table 3. Continued

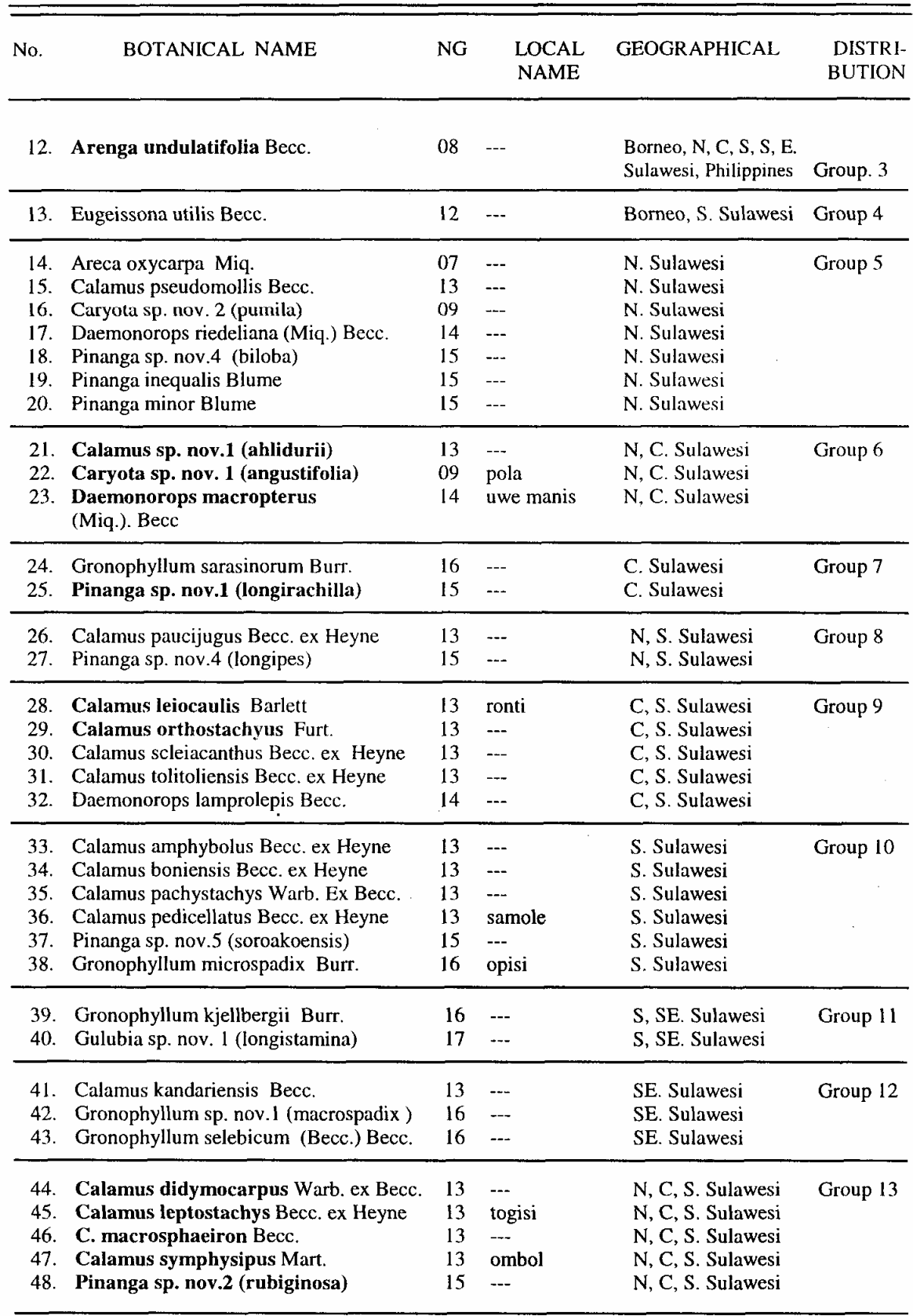


Table 3. Continued

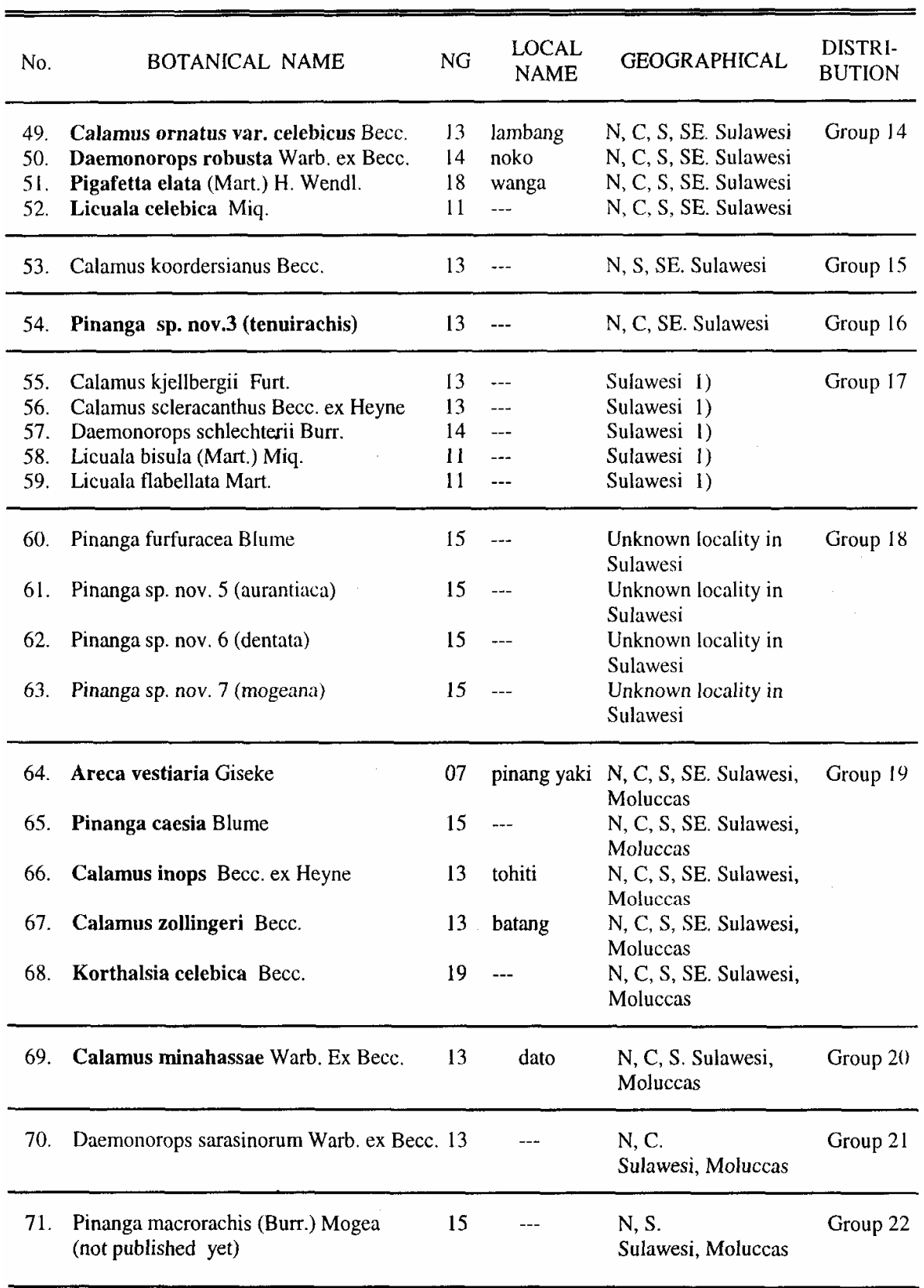

Source: Mogea, 2000

Names in bold are the palms found in the LLNP, 1) = specimens not available in $B O$, $\mathrm{G}=$ Genus number 
While the number of species in Gunung Potong and Tongoa is the same (23 in 7 genera), the species composition and population sizes are different (Table 1). Pigafetta is only found in Gunung Potong and Korthalsia only in Tongoa. Thirteen species were found in both Gunung Potong and Tongoa, among them 8 species have high absolute and relative frequency values (Table 1), meaning that those species occur in most of the 57 subplots (namely 27 subplots in Gunung Potong and 30 subplots in Tongoa). Calamus ornatus var. celebicus occurred in 41 subplots (10.66\%), Pinanga caesia in 40 subplots (10.40\%, Fig. 3 - 5), Arenga pinnata in 33 subplots (8.58\%), Daemonorops sp.3 in 32 subplots (8.32\%), Calamus didymocar-pus in 29 subplots (7.54\%), Calamus sp.4 (rapid spines) in 29 subplots (7.54\%), Caryota mitis in 28 subplots (7.28\%), and Areca vestiaria in 21 subplots (5.46\%). Of the 10 species found only in Gunung Potong, Calamus aff. C. paspalanthus is the most significant occurring in 9 subplots (2.34\%). Likewise 10 species were only found in Tongoa, 4 species had much higher absolute and relative frequency values namely Calamus aff. C. reinwardtii occurred in 18 subplots (4.68\%), Arenga undu-latifolia in 14 subplots (3.64\%), Daemonorops sp.l (didymophylla) in 12 subplots (3.12\%), and Korthalsia celebica in 10 subplots (2.60\%). These figures on palm diversity may change as'a result of further identification and further study as more plots are established.

Outside the Gunung Potong and Tongoa plots, other species of palms were found such as Calamus macrosphaerion var. macrosphaerion and C. orthostachyus in Gunung Malemo and Moa (Kramadibrata \& Dransfield 1992); 'ronti' (Calamus leiocaulis) and 'togisi' (C. leptostachys) in Moa (Siebert 1997).

A study on the role of rattan resources in the Moa and $\mathrm{Au}$ in the southern part of the Park has been done by Siebert (1997). It revealed that 'togisi' (Calamus leptostachys), 'ronti' (C. leiocaulis), 'lambang '(C. ornatus var. celebicus), 'batang' (C. zollingeri), and 'noko' (Daemonorops robusta) are the important rattans which produced a quite good rural cash income.

Other palms outside the two above mentioned plots are Caryota sp. nov.l (angustifolia) in Gunung Malemo (Zumaidar 2001), this species is solitary as $C$. rumphiana (Fig. 2); Licuala celebica and Livistona rotundifolia were common and widespread throughout the Park (personal observation); Pinanga sp. nov.l (longirachilla), Pinanga sp. nov.2 (rubiginosa), and Pinanga sp. nov.3 (tenuirachis) were found in and around Gimpu (Sinaga 2000). The rachillae of P. caesia and Pinanga sp. nov.2 (rubiginosa) are set up in many planes, the leaf sheath is dull green to bluish deep green in P. caesia (Fig. 2 - 4), while it is reddish orange in Pinanga sp. nov.2 (rubiginosa). The rachillae of Pinanga sp. nov.l (longirachilla) and Pinanga sp. nov.3 (tenuirachis) are set up in one plane, the leaf sheath is yellowish green in Pinanga sp. nov.l (longirachilla) and it is yellow in Pinanga sp. nov.3 (tenuirachis).

Pinanga celebica was not listed in the current Sulawesi palms (Table 3) due to uncertainty of its existence. The story of this taxon started in 1871, when Scheffer described Pinanga patula var. celebica based on the specimen of Riedel s.n. The label was annotated with the plant coming from Gorontalo - North Celebes, but in 
BIOTROPIA NO. 18, 2002
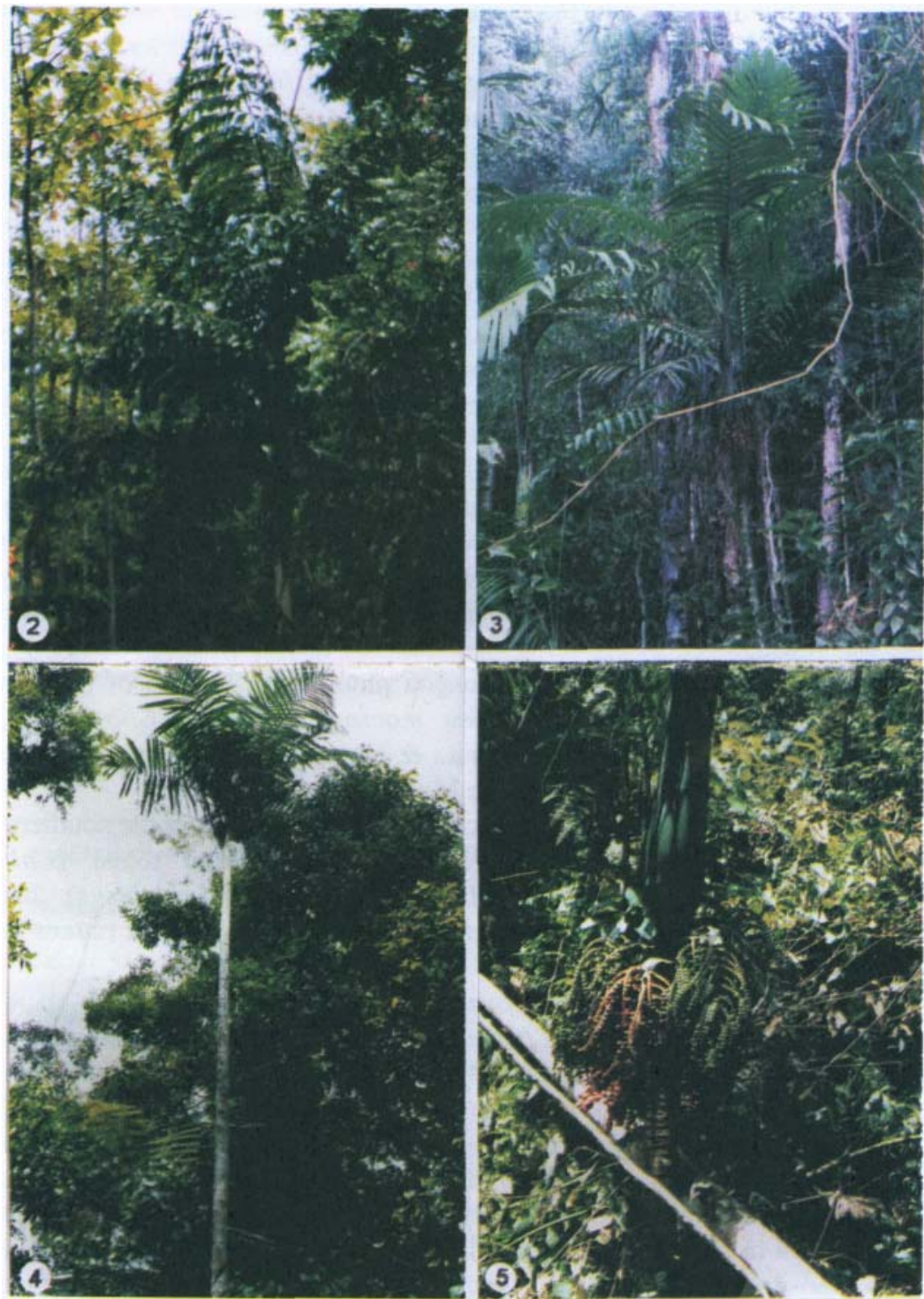

2. Solitary Caryota rumphiana, stem $6 \mathrm{~m}$ long

3. Solitary Pinanga caesia, stem $7 \mathrm{~m}$ long, $12 \mathrm{~cm}$ in diameter

4. Solitary Pinanga caesia (living collection of Mogea 7467), stem $10 \mathrm{~m}$ long, $16 \mathrm{~cm}$ in diameter

5. Top portion of Pinanga caesia (living collection of Mogea 7467) shows top portion of the stem, infructescences, and leaf sheath $80 \mathrm{~cm}$ long, 

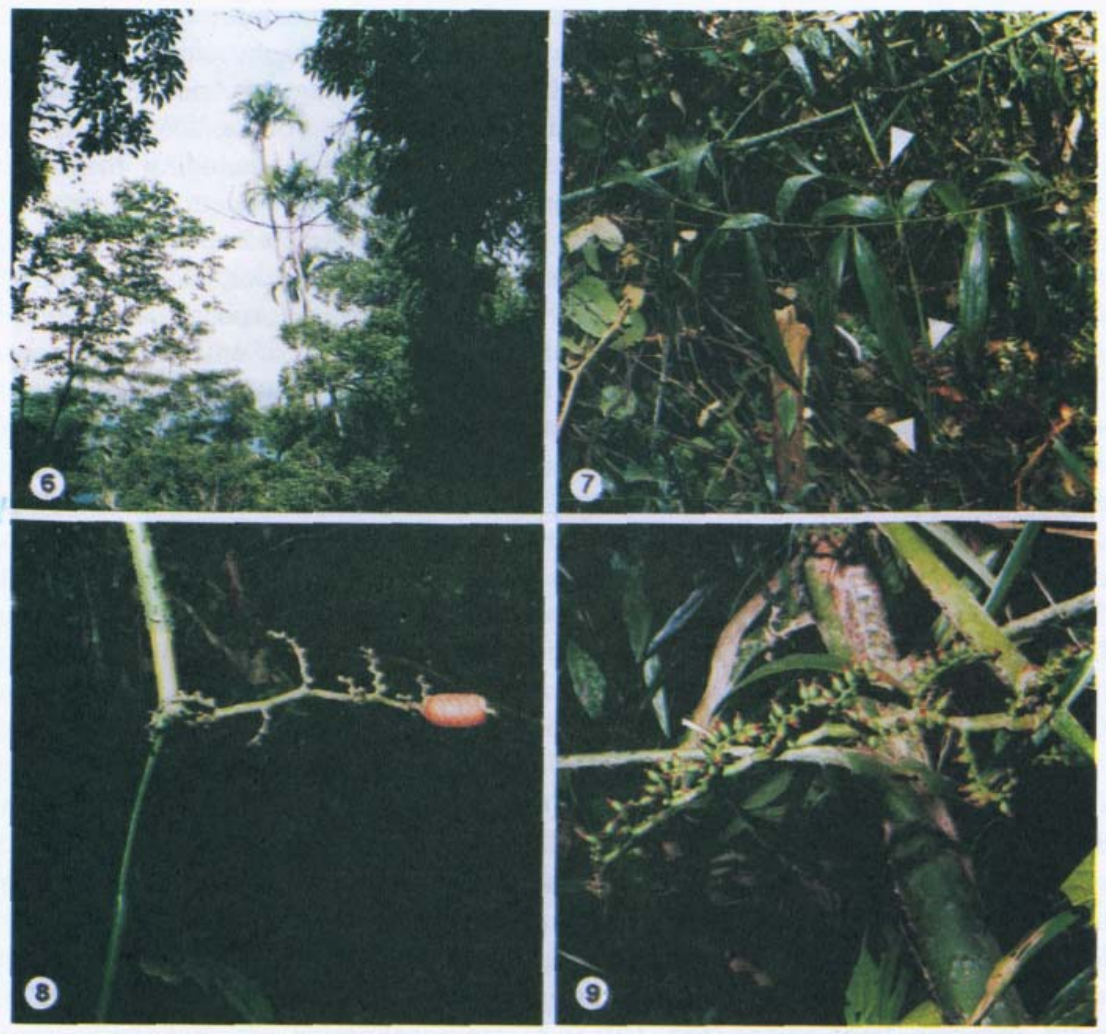

6. At the center are three tree palms of Pigafetta data, the tallest is about $25 \mathrm{~m}$

7. Calamus sp.l (knee no spine; living collection of Mogea 7466), leaf rachis $140 \mathrm{~cm}$ long, cirrus $100 \mathrm{~cm}$ long, white triangle indicates the rachillae bearing reddish brown fruit

8. Top portion of infructescence of Calamus sp. 1 (knee no spine, Mogea 7466) bearing one ellipsoid reddish brown almost ripe fruit of $15 \mathrm{~mm}$ long and $7 \mathrm{~mm}$ in diameter

9. Base portion of infructescence of Calamus sp. 1 (knee no spine, Mogea 7466) bearing many very young fruits, leaf sheath $15 \mathrm{~mm}$ in diameter

1876 he changed its status to Pinanga celebica. He wrote that the plant clusters, had whitish leaves, a long inflorescence rachis with numerous rachillae, and obovoid fruits. This character diagnosis, however, is inadequate for identification to the species level as they are too general. Moreover the clustered habit is not found in any of the East Malesian Pinanga (Sinaga 2000). 
Betel nut palm or 'pinang sirih' Areca catechu and coconut palm or 'kelapa' Cocos nucifera is often planted in a village garden, the former usually used for a living fence to mark boundaries. Sugar palm or 'aren' or 'saguer' Arenga pinnata is often grown in gardens around the Park, and are often found on the forest border or in disturbed primary lowland and montane forest. Hence, including these last mentioned palms, the number of species or taxa so far known to occur in and around the park is 48 represented by 11 genera (Table 2) namely Areca 2 species, Arenga 2 species, Calamus 26 species, Caryota 3 species, Cocos 1 species, Daemonorops 5 species, Korthalsia 1 species, Licuala 1 species, Livistona 1 species, Pigafetta 1 species, and Pinanga 4 species. Including here are some other of unidentified genera (Table 2 and Appendix 1). As shown in Appendix 1, many of the herbarium specimens are sterile, though it is still important to figure out the diversity but to describe or to identify up to the genus level is often inadequate. Calamus are often difficult to separate from Daemonorops when they are all still in the vegetative stage. On the other hand, the morphology of seedling, sapling, juvenile, and mature in the palm species is often distinct. Therefore, adequate observation in the field, fertile and correct collection for the herbarium specimens is very necessary. If this field study is successfully done, it is believed that there might be some new taxa particularly of Calamus and Daemonorops, but also of Pinanga, Licuala and Caryota.

Most Calami in and around the Park are clustering rattans but few of them are solitary such as in Calamus inops, C. leptostachys, and C. symphysipus. Stem diameter varies from 6-40 mm, with the leaf sheath diameter varying from 8-45 $\mathrm{mm}$. The smallest cane is $C$. leiocaulis and the largest is $C$. zollingeri. Petioles are mostly green, but are reddish brown in Calamus sp.14 (Mogea 7465, Fig. 13). The leaf sheath and the petiole are covered by scarcely small spines such as in $C$. ornatus var. celebicus; but Calamus sp.4 (rapid spines; Mogea 7461) are covered by slender, rapid, greenish, large spines (Fig. 10); in C. macrosphaerion var. macrosphaerion, by rapid, flat, triangular, blackish brown spines (Fig. 12); and in Calamus sp.14 (Mogea 7465) by scarcely brown, flat, triangular comblike spines (Fig. 13). The specimens of Mogea 746.5 might be Calamus sp. nov.l (ahlidurii) or Daemonorops macropterus. When already matured, the identity of the specimen will be much easier to determine as the difference between Calamus and Daemonorops can only be seen after the flowering stage, namely the peduncular bract in Calamus is tubular and attached to the rachis of the inflorescence while it is leafy-like and deciduous in Daemonorops. Calamus sp.2 (ligule; Mogea 7456) has the only conspicuous ocrea or ligule (Fig. 11). Calamus in Sulawesi are mostly cerriate, hence from this point the vegetative characters of Calamus are not different from Daemonorops. However, sometimes the species identity can be found based on the number of the leaflets on either side of the rachis, mostly Daemonorops has regular (rarely in groups) and very narrow leaflets compared to Calamus. The number of leaflets in Daemonorops is mostly on the average between 40 to 80 leaflets, while in a small diameter cane of 
Calamus, the leaflets are very much less in number, usually 6 to 16 such as in Calamus minahassae which has only 12 leaflets set up in 6 groups, each group consisting of one or two leaflets. When ripe, the fruit colour is pale greenish-white such as in Calamus macrosphaerion (Fig. 14) or glossy white (Fig. 15) as in Calamus sp. 1 (knee no spine) or black as in Calamus zollingeri.

Native palms in Sulawesi are represented by 71 species in 19 genera (Table 3) based on observations from about 20 sites all over Sulawesi (Mogea 2000) updated by recent current examination of the specimens and recent field work. Pending further identification, the number of genera and palm species in and around the Park represents about $58 \%$ and $68 \%$ of genera and species of Sulawesi's palm flora, respectively.

Metroxylon sagu was probably planted long ago for their edible carbohydrate and is considered here. as an introduced species. Its original distribution is in Moluccas and New Guinea. Sagu baruk (Arenga microcarpa) has apparently been cultivated in District Sangir Talaud for 80 years already. Its original distribution is the same as for the sago palm. Sihombing et al. (1980) incorrectly identified it as $A$. obtusifolia. The sagu baruk covers about 19890 ha or about $30 \%$ of the total agricultural area in the district (Sihombing et al. 1980). 'Salak Pangu', Salacca zalacca var. amboinense, was cultivated for some decades in Pangu Village, District Minahasa, North Sulawesi . The salak pangu now is popular as an edible fresh fruit in North Sulawesi. It was said that the cultivation started in 1961. Now salak pangu plantations cover about 654 ha with about 2 million individual plants (Dannie 1999). Other introduced palms are mostly indoor or outdoor ornamental plants. So far known, the number of the introduced palms in Sulawesi is 20 (Table 4), including the palm for plantation namely 'sawit' or oil palm Elaeis guineensis. Based on their origin, the introduced palms consist of 12 groups. These introduced palms were found in Palu and on the way to the Park. 
BIOTROPIA NO. 18, 2002
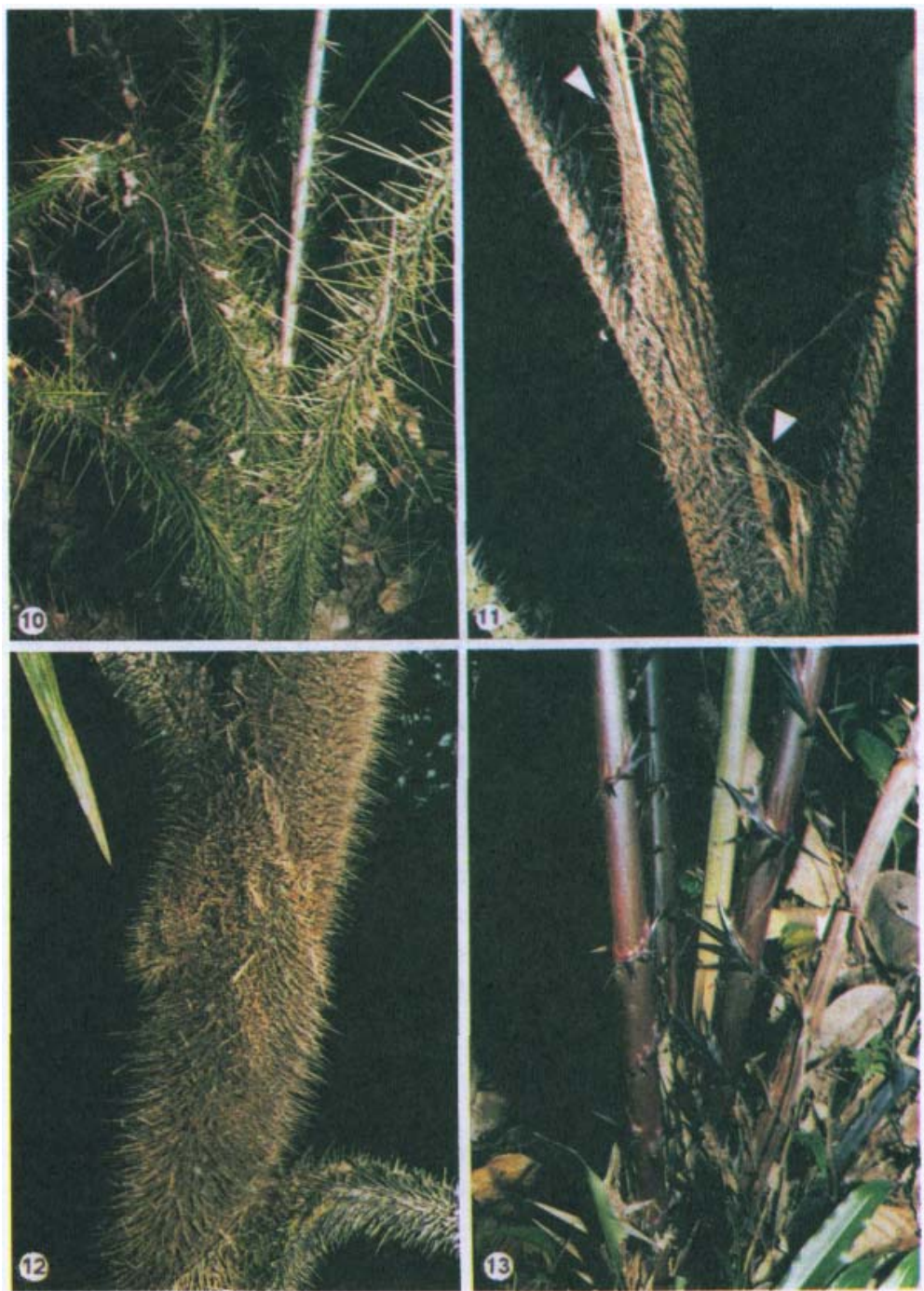

10. Base portion of young Calamus sp.4(rapid spines, living collection of Mogea 7461) shows $50 \mathrm{~cm}$ long petioles and leaf sheaths covered by rapid slender long greenish white spines

11. Top portion of young $1.5 \mathrm{~m}$ tall Calamus sp.2 (ligule, living collection of Mogea 7456) stows top of leaf sheaths bearing conspicuous young entire and old tattered ocrea

12. Middle portion of Calamus macrosphaerion var macrosphaerion (living collection of Mogea 7470) shows leaf sheaths of $4 \mathrm{~cm}$ in diameter and petioles covered by rapid flat triangular blackish brown spines

13. Base portion of young Calamus sp. (living collection of Mogea 7465) shows reddish brown petioles covered by scarcely black flat triangular combed-like spines 

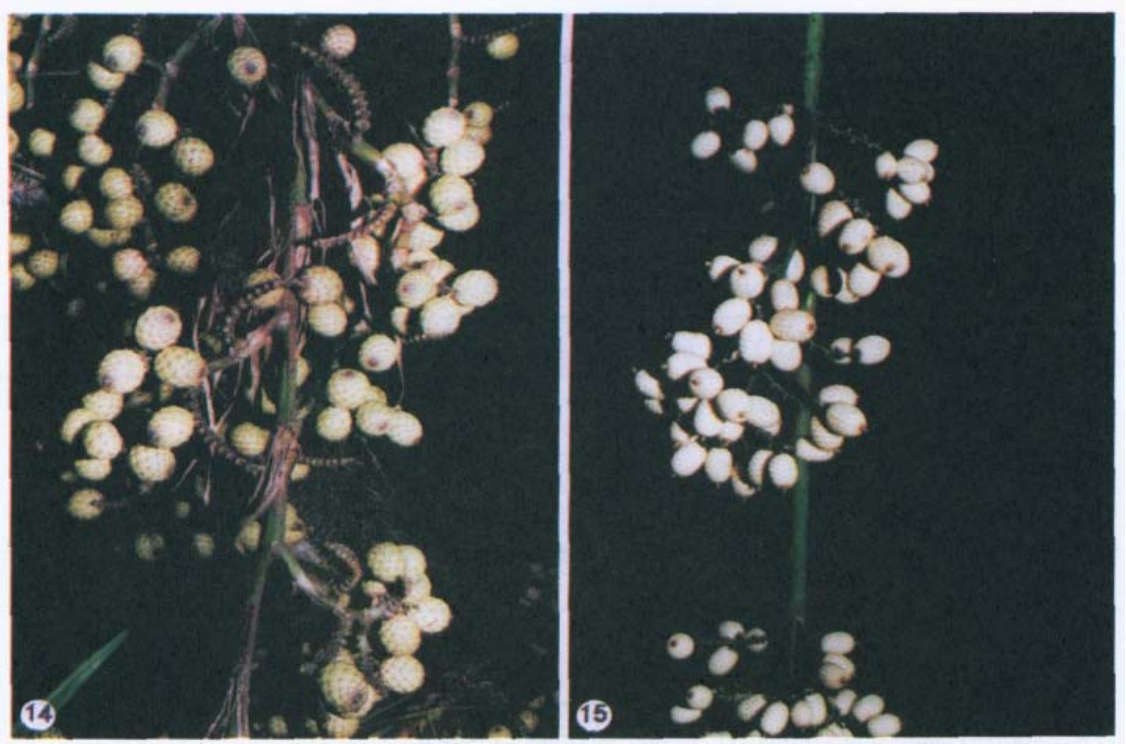

14. Nearly top portion of infructescence of Calamus macrosphaerion (living collection of Mogea 7470) bearing pale greenish white almost ripe ellipsoid fruits of $10 \mathrm{~mm}$ in diameter

15. Middle portion of infructescence of Calamus sp. 1 (knee no spine, living collection of Mogea 7487) bearing white ellipsoid ripe fruits $8 \mathrm{~mm}$ in diameter

Table 4. Checklist of introduced palms in Sulawesi and their origin

\begin{tabular}{|c|c|c|c|c|}
\hline NO. & BOTANICAL NAME & LOCAL NAME & ORIGIN & GROUP \\
\hline 01. & $\begin{array}{l}\text { Elaeis guineensis Steud. } \\
\text { Phoenix reclinata Jacq. }\end{array}$ & $\begin{array}{l}\text { sawit } \\
\text { korma hias }\end{array}$ & $\begin{array}{l}\text { Tropical Africa } \\
\text { Tropical Africa }\end{array}$ & 1 \\
\hline $\begin{array}{l}03 . \\
04 . \\
05\end{array}$ & $\begin{array}{l}\text { Chrysalidocarpus lutescens H. Wendl. } \\
\text { Neodypsis decaryi Jumelle } \\
\text { Hyophorbe lagenicaulis (L.H. Bailey) } \\
\text { H.E. Moore }\end{array}$ & $\begin{array}{l}\text { palem kuning } \\
\text { palem segitiga } \\
\text { palcm botol }\end{array}$ & $\begin{array}{l}\text { Madagascar } \\
\text { Madagascar } \\
\text { Madagascar }\end{array}$ & 2 \\
\hline 06. & Rhapis excelsa Henry ex Rehder & waregu & South Asia & 3 \\
\hline $\begin{array}{l}07 . \\
08 . \\
09 .\end{array}$ & $\begin{array}{l}\text { Cyrtostachys renda Blume } \\
\text { Salacea zalacca (Gaertn.) Voss var. zalacca } \\
\text { S. zalacca var. amboinensis Becc. }\end{array}$ & $\begin{array}{l}\text { pinang merah } \\
\text { salak } \\
\text { salak pangu }\end{array}$ & $\begin{array}{l}\text { West Malesia } \\
\text { West Malesia } \\
\text { West Malesia }\end{array}$ & 4 \\
\hline
\end{tabular}


BIOTROPIA NO. 18, 2002

able 4. Continued

\begin{tabular}{|c|c|c|c|c|}
\hline No. & BOTANICAL NAME & LOCAL NAME & ORIGIN & GROUP \\
\hline $\begin{array}{l}10 . \\
11 .\end{array}$ & $\begin{array}{l}\text { Arenga microcarpa Becc. } \\
\text { Metroxylon sagu Rottb. }\end{array}$ & $\begin{array}{l}\text { sagu baruk } \\
\text { sagu }\end{array}$ & $\begin{array}{l}\text { Moluccas, N.Guinea } \\
\text { Moluccas, N. Guinea }\end{array}$ & 5 \\
\hline 12. & $\begin{array}{l}\text { Actinorhytis calapparia } \\
\text { (Blume) H. Wendl. 1) }\end{array}$ & jambe sinagar & New Guinea & 6 \\
\hline 13. & Ptychosperma macarthurii $\mathrm{H}$. Wendl. & palem papua & New Guinea & 7 \\
\hline 14. & Veithcia merrillii (Becc.) H.E. Moore & palem putri & Philippines Isl. & 8 \\
\hline 15. & $\begin{array}{l}\text { Archontophoenix alexandrae H. Wendl. } \\
\text { \& Drude }\end{array}$ & palem aleksander & Queensland, Australia & 9 \\
\hline 16. & Wodyetia bifurcata $\mathrm{A}$. Irvine & palem ekor bajing & Queensland, Australia & \\
\hline 17. & Licuala grandis $\mathrm{H}$. Wendl. & palem kol & New Britain & 10 \\
\hline 18. & Pritchardia pacifica Seem. \& H. Wendl. & palem pasifik & Fiji Isl. & 11 \\
\hline $\begin{array}{l}19 . \\
20 .\end{array}$ & $\begin{array}{l}\text { Roystonea regia O.F. Cook } \\
\text { Thrinax radiata Lodd ex Deef. }\end{array}$ & $\begin{array}{l}\text { palem raja } \\
\text { palem bintang }\end{array}$ & $\begin{array}{l}\text { Tropical America } \\
\text { Tropical America }\end{array}$ & 12 \\
\hline
\end{tabular}

1) Actinorhytis calapparia (Blume) H. Wendl. \& Drude ex Scheti.

It is listed that native palms of Sulawesi consist of 71 species and can be divided into 22 groups based on local and regional plant geographical distribution, namely Tropical Asia, Malesia, Borneo; North, Central, South, and Southeast Sulawesi; unknown locality in Sulawesi, and Moluccas (Table 3). The number of palm species endemic to Sulawesi is moderately high (70.83\%) namely 51 out of total native 71 species. However, only two species namely, Gronophyllum sarasi-norum and Pinanga sp. nov.l (longirachilla), are endemic to Central Sulawesi (Table 3, Group 7). The latter species is so far known only from Gimpu (Fig. 1) the south portion of the Park (Table 3 and Appendix 1).

\section{CONCLUSION}

This preliminary study on palms in and around the Lore Lindu National Park, including observations on 1350 m by 20 m rectangular plot sites in Gunung Potong, a $1500 \mathrm{~m}$ by $20 \mathrm{~m}$ rectangular plot in Tongoa, herbarium specimens collected from Gunung Nokilalaki, Sopu Valley, Moa, and Gunung Malemo revealed that there are 48 species belonging to 11 genera. Calamus and Daemonorops are very dominant as shrubs and climbers. The largest genus in the Park-is Calamus with 25 species, followed by Daemonorops (6 species) and Pinanga (4 species). However, more 
fertile collections of these genera are still required. It is therefore expected that some undescribed and locally endemic palms may still be found as Calamus, Daemonorops, Licuala, Caryota and Pinanga.

\section{ACKNOWLEDGMENTS}

The author would like to express his sincere gratitude to STORMA for providing funds which made the conduct of this study possible. Cordial appreciation is also addressed to the officers of Lore Lindu National Park who have kindly provided facilities during the field work and the Indonesian-German Research Team, particularly to Dr. Paul Kesler.

Thanks are also due to Dr. Sri S. Tjitrosoedirdjo of SEAMEO BIOTROP for her suggestions to improve the manuscript, and Dr. Arie Budiman, Head of the Research Centre for Biology, LIPI, Bogor, for allowing the author to conduct the study.

\section{REFERENCES}

Dannie, A.T.E. 1999. Salak Pangu "Imigran" asal Bali Trubus 30 9358): 69.

Dransfield, J. 1974. A Short Guide to Rattans. BIOTROP (Seameo Regional Centre for Tropical Biology). Bogor. Mimeographed. 69 p.

Dransfield, J. 1998. Pigafetta. Principes 42 (1): 34 - 40.

Kramadibrata, P. \& J. Dransfield. 1992. Calamus inops (Palmae: Calamoideae) and its relatives. Kew Bulletin 47 (4): 581-593.

Mogea, J.P. \& Suhardjono. 1981. Struktur dan komposisi pepohonan di Gunung Malemo - Sulawesi Tengah. Paper presented at the National Biological Seminar XV.Semarang Indonesia, June 26 - 28. Mimeographed. 14 p.

Mogea, J.P. 2000. Status konservasi palem Indonesia, khususnya Sulawesi. Paper presented at the National Biological Seminar XVI, Bandung, July 25 - 27, 2000. Mimeographed. 15 p.

Mueller-Dombois, D. \& H. Ellenberg. 1974. Aims and methods of vegetation ecology. New York, ca $160 \mathrm{p}$.

Siebert, S.F. 1997. Economically important rattans of Central Sulawesi, Indonesia. Principes 41 (1): 42 -46.

Sinaga, N.I. 2000. Pinanga Blume (Arecaceae) in East Malesia. M.Sc. Thesis. Bogor Agriculture University, Darmaga, Bogor Indonesia, $66 \mathrm{p}$.

Steenis, C.G.G.J., van. 1950. The technique of plant collection and preservation in the tropics. Flora Malesiana I (1): xlv - Ixix. 
BIOTROPIA NO. 18, 2002

The Nature Conservancy. 2000. Lore Lindu National Park. Indonesia Program Information Sheet SPPI. Jakarta. Leaflet 2 p.

Uhl, N.W. \& J. Dransfield. 1987. The Genera Palmarum. Alien Press. Lawrence Kansas. 610 p.

Zumaidar. 2001. Taxonomy and species relationship of Indonesian Caryota (Palmae). M.Sc. Thesis. Bogor Agriculture University, Darmaga, Bogor Indonesia, 44 p. 
Preliminary study on the palm flora of the Lore Lindu National Park - Johanis P. Mogea

\section{Appendix 1. Specimens examined:}

Note: Plant name: Locality, elevation, phenological state (st: sterile, ffl: female flower, mfl: male flower, fl: hermaphrodite flower, fr: fruit), date, collection number, deposited Hersbarium, with the exclamation point means that the author has seen the specimens)

Areca vestiaria: Tongoa, foot path to the summit of Mt. Nokilalaki, alt. 750 in, fr.02-03-01, Mogea 7473 (BO!, CEB!)

Arenga undulatifolia: Tongoa, foot path to the summit of Mt. Nokilalaki, alt. 750 in, st.02-03-01, Mogea 7474 (BO!; CEB!)

Calamus didymocarpus : Mt. Nokilalaki, Toro, fr.23-04-75, Meijer 9465 (BO!).

Calamus inops: Kulawi, Moa, Mt. Malemo, mfl.24-10-77, Mogea 1474 (BO!); ditto., Mogea 1475 (BO!); ditto., Mogea 1476 (BO!); ditto., Mogea 1477 (BO!, K). Tongoa, foot path to the summit of Mt. Nokilalaki, alt. 750 m, ffl.05-03-01, Mogea 7490 (BO!; CEB!).

Calamus macrosphaerion var. macrosphaerion: Kulawi, Mt. Malemo, fr.20-10-77, Mogea 1347 (BO!).

Calamus minahassae: Sopu Valley, fr.05-05-79, de Vogel 5212 (BO!, L).

Calamus omatus var. celebicus : Sopu Valley, fr.26-04-79, de Vogel 5054 (BO!, L); ditto., 02-05-79, de Vogel 5172 (BO!); Kulawi, Moa, fr.22-10-77, Mogea 1411 (BO!).

Calamus orthostachyus: Kulawi, Moa, Mt. Malemo, fr.18-10-77, Mogea 1329 (BO!, K, L), ditto., Mogea 1330, mfl. (BO!).

Calamus symphysipus: Tongoa, foot path to the summit of Mt. Nokilalaki, alt. 750 m, st.02-03-01, Mogea 7472 (BO!, CEB!).

Undeterminate Calamus from Tongoa, foot path to the summit of Mt. Nokilalaki, alt. $750 \mathrm{~m}$ : Calamus aff. C omatus, st.03-03-01, Mogea 7478 (BO!, CEB!), ditto, mfl.03-03-01, Mogea 7479 (BO!, CEB!). Calamus aff. C. reinwardtii: path to the st.02-03-01, Mogea 7476 (BO!, CEB!); Calamus sp.4 (rapid spines), st.18-11-00, Mogea 7442 (BO!, CEB!) = Mogea 7461 (see at Gunung Potong alt. $950 \mathrm{~m}$ ); Calamus sp.7 (tattered ligule), st.03-03-01, Mogea 7477 (BO!, CEB!); Calamus sp.8 (tuberosus), fr.03-0301, Mogea 7486 (BO!, CEB!); Calamus sp.9 mfl.05-03-01, Mogea 7488 (BO!, CEB!).

Undeterminate Calamus from Gunung Potong, alt. 850 m: Calamus sp.8 (tuberosus), st.26-02-01, Mogea 7455 (BO!, CEB!). Calamus sp.2 (ligule), st.27-02-01, Mogea 7456 (BO!, CEB!). Calamus sp.6 (soft white spine), mfl.01-03-01, Mogea 7471 (BO!, CEB!).

Undeterminate Calamus from Gunung Potong, alt. 950 m: Calamus sp.4 (rapid spines), st.27-02-01, Mogea 7461 (BO!, CEB!) = Mogea 7442 (see at Tongoa ); ditto., alt. 1200 m, mfl.01-03-01, Mogea 7468 (BO!, CEB!).

Undeterminate Calamus from Mt. Roroka, Timbu: Calamus sp.10, st.20-05-79, de Vogel 5482 (BO!); ditto., fr. 13-05-79, de Vogel 5334 (BO!).

Undeterminate Calamus from Sopu Valley: Calamus sp.ll, st.05-05-79, de Vogel 5209 (BO!); st.05-05-79, de Vogel 5218 (BOI).

Undeterminate Calamus from Mt. Nokilalaki: Calamus sp.12, st.22-04-75, Meijer 9438 (BO!); ditto., st. 0405-75, Meijer 10021 (BO!).

Undeterminate Calamus from Kulawi, Moa: Calamus sp.13, st.14-10-77, Mogea 1290 (BO!); ditto., st. 1810-77, Mogea 1324 (BO!), ditto., Mogea 1325 (BO!); ditto., Mogea 1326 (BO!); ditto., Mogea 1328 (BO!); ditto., st.22-10-77, Mogea 1433 (BO!) 
Caryota sp. nov.l (angustifolia); Kulawi, Moa, Mt. Malemo, alt. 1200 m, fr.23-10-77, Mogea 1441 (BO!); ditto., fl.+fr.24-10-77, Mogea 1473 (BO!)

Daemonoropx macropterus: Sopu Valley, fr.22-05-79, de Vogel 5326 (BO!); Tongoa, foot path to the summit of Mt. Nokilalaki, alt. 750 m, st.05-03-01, Mogea 7491 (BO!; CEB!)

Korthalsia celebica: Kulawi, Moa, Mt. Malemo, st.,23-10-77, Mogea 1462 (BO!); ditto., Mogea 1463 (BO!)

Pinanga caesia Blume: Palu: Sopu Valley, alt. 1000 m, fr. 12-04-79, de Vogel 5064 (BO!); Gunung Potong, alt. 950 m, fr.28-02-01, Mogea 7467 (BO!, CEB!);

Parigi, alt. 800 m, fr.17-04-75, Meijer 9378 (BO!); Kulawi, Gimpu, Moa, alt. 1200 m, st.19-10-77, Mogea 1343 (BO!); ditto., fr.l 1-10-77, Mogea 1271 (BO!); ditto., fr.l 1-10-77, Mogea 1274 (BO!); ditto., Mogea 1275 (BO!): Mt. Malemo, fr.23-10-77, Mogea 1443 (BO!).

Pinanga sp. nov.l (longirachilla): Kulawi, Gimpu, alt. 600 m, fr.l 1-10-77, Mogea 1275 (BO!); Mt. Malemo, alt. 1000 m, fr.17-04-79, Mogea 1443 (BO!).

Pinanga sp nov.2 (rubiginosa): East of Tongoa, alt. 720 m, fr.02-03-81, Johannxxal, Nybom \& Riehe 126 (BO!).

Pinanga sp. nov.3 (tenuirachis): Kulawi, alt. 600 m, fr. 11-10-77, Mogea 1271 BO!). 